\title{
Violência doméstica contra a mulher - com a fala, eles, os homens autores da violência
}

\author{
Domestic violence against a woman - with the \\ speak: they, the authors of violence
}

\author{
Amália Einhardt ${ }^{a}$ \\ (1) https://orcid.org/0000-0003-1807-1491 \\ Simone Sobral Sampaio ${ }^{a}$ \\ (D) https://orcid.org/0000-0003-3452-5414
}

Resumo: Este artigo tem como objetivo analisar a alegação apresentada por homens autores de violência doméstica, contra as suas companheiras (ou ex-companheiras), pelo cometimento de seus atos. Os fatores relatados por esses homens demonstram o seu não reconhecimento enquanto sujeitos autores de violência contra a mulher. Desse modo, os motivos alegados podem ser importante matéria para a construção de políticas públicas de enfrentamento e prevenção, bem como estratégias interventivas junto a esses sujeitos.

Palavras-chave: Homens autores de violência doméstica. Violência doméstica contra mulher. Relações de gênero.

\begin{abstract}
The purpose of this article is to analyze the allegations made by male domestic violence perpetrators against their female partners (or former female partners) for the commission of their acts. The factors reported by these men demonstrate their non-recognition as perpetrators of violence against women. Thus, the reasons given may be important matter for the construction of public policies of coping and prevention and intervention strategies with these subjects.
\end{abstract}

Keywords: Male perpetrators of domestic violence. Violence domestic against women. Gender relationships. 


\section{Introdução}

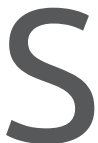

abe-se que a violência contra as mulheres é presente na sociedade. Todos os dias mulheres morrem pelo simples fato de serem mulheres. Este artigo irá atentar, especificamente, para a violência doméstica cometida por companheiros/ex-companheiros contra suas parceiras. Terá como base a pesquisa intitulada "Compreendendo a violência doméstica a partir dos depoimentos de homens autores de violência contra a mulher", ${ }^{1}$ realizada em 2018. Os sujeitos ${ }^{2}$ dessa pesquisa foram homens autores de violência contra mulheres, os quais estavam detidos na Casa do Albergado de Florianópolis. Seu objetivo foi analisar os fatores, alegados pelos próprios homens, por terem violentado suas companheiras/ex-companheiras.

Por anos considerou-se que a violência doméstica fosse algo a se resolver entre quatro paredes, como revela a expressão popular "em briga de marido e mulher, não se mete a colher", porém, após muita luta e resistência do movimento feminista, a violência doméstica começou a deixar de ser um assunto privado, tornando-se público e, principalmente, uma questão política marcada por assimétricas relações de poder.

No Brasil, a legislação que defende e orienta mulheres que estão em situação de violência doméstica é a Lei n 11.340/06, mais conhecida como Maria da Penha. Essa lei, além de ser considerada o principal documento jurídico para lutar contra a violência doméstica, também retrata um sujeito específico, aquele que comete a violência, que também a naturaliza, o principal responsável por reproduzir ações violentas: o homem autor de violência. E é sobre esse “cara” que o presente artigo irá discorrer.

A pesquisa - anteriormente citada - revelou que, do conjunto das alegações emitidas por eles, os fatores apresentados podem ser

\footnotetext{
1 Disponível em: https://repositorio.ufsc.br/handle/123456789/195738. Acesso em: 27 mar. 2020.

2 Foram entrevistados sete homens que estavam detidos por violência doméstica contra a mulher.Todos participaram da entrevista sob livre e espontânea vontade, respondendo questões que auxiliassem a desvendar e analisar os principais fatores que os levaram a agredir suas companheiras/ex-companheiras.
} 
reunidos da seguinte forma: "O motivo sempre está fora, como se o autor de violência não tivesse em si a causa de suas ações"; "Impulsividade"; "A ambiguidade da mulher"; "Desconsideração do seu ponto de vista” e, ainda, "O autor da violência se vê como vítima".

Os relatos que serão apresentados abaixo, além de revelarem a compreensão dos atos de violência pelos próprios autores, podem servir como elementos indicativos não apenas da gravidade e naturalização da violência doméstica, mas também potencializar a construção de estratégias destinadas ao enfrentamento desse tipo de violência.

\section{Desenvolvimento}

Ao "justificar" as atitudes violentas, os entrevistados remeteram a responsabilidade dos seus atos a outros fatores e pessoas. Como se eles não tivessem em si mesmos a causa de suas próprias ações, fizeram referência ao álcool, ciúmes e até mesmo à própria mulher em situação de violência doméstica.

Como afirma "P4": "Às vezes quando eu bebo, sempre tem alguma provocação, eu caio, eu acabo caindo na provocação" (Vieira, 2018, p. 39-40). Ele utiliza como elemento desencadeador para o seu próprio ato de beber o comportamento incompreensível de sua companheira. Reconhece que seu alcoolismo o influencia na sua perda de controle racional, masainda assim responsabiliza a esposa por sua escolha individual.

Desconsiderar a situação de alcoolizado do companheiro responsabilizaria a mulher pela reclamação realizada. Além disso, há tolerância e permissividade social quanto à ingestão de bebidas alcoólicas por homens, mesmo que de modo excessivo.

Muitas vezes, beber masculiniza. Assim como dizer para os amigos que teve muitas relações sexuais é uma forma de se apresentar como "mais homem", beber e, em alguns casos, beber muito, pode ser também uma forma de parecer do mesmo modo. (Nascimento, 2016, p. 59) 
Inclusive observa-se que a expressão "beber como homem" intensifica a masculinidade hegemônica, que caracteriza o homem "branco, ocidental, de classe dominante, provedor, heterossexual, forte e viril" (Kimmel, 1997, apud Beiras, et al., 2007), constituindo-lhe como ser incapaz de manifestar suas emoções, suas fragilidades, sua afetividade, sob pena de parecer inferior.

O álcool é uma droga lícita de fácil acesso e propagada cultural e midiaticamente. No sexo masculino, percebe-se que tal influência é exercida com maior frequência. Apesar de o número de mulheres alcoolistas estar crescendo, é reconhecido que culturalmente nesta sociedade baseada pelo patriarcalismo, homens são influenciados a começarem a beber mais cedo, e são "bem-vistos/admirados" por terem a capacidade de ingerirem grandes quantidades de álcool. Inclusive é visível, em comerciais de famosas marcas de cervejas brasileiras veiculados na televisão, o uso da ideia de sensualidade do corpo feminino para chamar a atenção de homens heteronormativos.

Outros participantes da pesquisa associaram em suas falas a relação entre alcoolismo e conflitos conjugais.

[...] então ela achava que quando eu bebia eu me excedia demais, mas ela não percebia que era ela que fazia a gente se exceder, não vou dizer assim que eu to colocando a culpa nela né, não tô botando a culpa nela, tá, porque quando ela me conheceu, ela me conheceu daquele jeito [...]. (P5) ${ }^{3}$ (Vieira, 2018, p. 40)

O intransitivo lugar da masculinidade, cuja identidade dispensa relações, não necessita de complemento porque tem sentido completo. Nesse caso, o outro, ou melhor, a parceira é apenas um acessório na

3 Ao inserir álcool em seu organismo, o usuário fica propenso a alguns sintomas, como: diminuição das inibições de comportamento, de crítica, prejuízos no raciocínio e na concentração (Niscastre, 2011). "P5", ao ingerir bebidas alcoólicas, tinha seu comportamento alterado, mas em suas falas essa alteração era motivada pela sua ex-companheira. 
relação, alguém que deve se manter passiva e resignada diante do outro. Um "outro" forjado por uma masculinidade duplamente conservadora, seja porque ele mesmo mantém sua forma de ser inalterada, seja porque perpetua a ordem social.

Outro fator apresentado pelos homens entrevistados como um importante elemento de justificação dos atos violentos foi o ciúme relacionado com a ideia de que o homem tem posse da mulher.

[...] porque que ela tava mexendo no celular aqueles horário ali, e eu tava achando que até ela tinha outra pessoa, entendeu? [...] Assim parece que ela tava assim, assim simulando as coisas assim, entendesse, simulando assim um dizia uma coisa, outro dizia outra, entendesse. Ela não fez isso aí por ela própria, não. Ela não fez isso aí, ela só, só ela mesmo. Foi várias pessoas incentivando ela pra gente separar né. (P2) (Vieira, 2018, p. 41)

Na fala supracitada, "P2" demonstra não aceitar alguns comportamentos de sua ex-companheira, como: utilizar o celular no meio da noite, ter contato com o sexo masculino no serviço, e ele ainda acredita que a mesma foi manipulada por outras pessoas para se separar dele. Esse discurso, baseado em desconfiança e ideia de posse, traz novamente uma conexão do elemento, nesse caso o ciúme, com a masculinidade hegemônica, que "é normativa, diretamente influenciada pelo patriarcalismo, contém em seu interior qual é a melhor forma de ser homem, pratica e legitima o poder da subordinação de mulheres por homens" (Connell; Messerschmidt, 2013, apud Vieira, 2018, p. 21).

Um elemento que merece destaque é a suspeição que paira em outras figuras femininas como "influenciadoras negativas" sobre o comportamento de alguém, como se ela fosse facilmente manipulada, criando uma divergência com a orientação dada por aquele que, supostamente, deveria ter exclusividade na definição do comportamento da companheira.

Portanto, o discurso de "P2" mostra o quanto essa masculinidade interfere no dia a dia das relações pessoais, trazendo a ideia de que a mulher pertence ao homem e é um objeto seu, que ele tem poder 
perante ela, com direitos de fazer uso, inclusive, da força física contra o sexo feminino.

A ideia da posse continua evidente em outros discursos em que 0 relacionamento já havia terminado, mas o homem acreditava que ainda tinha responsabilidade/poder sobre sua ex-companheira. Como no caso de "P5", que foi detido ao descumprir uma medida de segurança, mas demonstra acreditar que só estaria em situação de privação de liberdade pelo fato de sua ex-companheira estar se relacionando com outra pessoa.

[...] porque ela chamou a polícia, ela chamou a polícia porque ela tava com o cara lá dentro e não queria que eu soubesse que o rapaz tava lá [...] eu sabia que ela ia chamar a polícia, eu só não sabia que o cara tava lá, que ela tava fazendo isso por causa do cara [...]. (P5) (Vieira, 2018, p. 41-42)

Esse entrevistado "justifica" fortemente a sua detenção porque sua ex-companheira seguiu em frente, como se o fato de ela estar com outra pessoa fosse "um artifício que lhe exime da culpa, e ainda a transfere para outro, no caso, a mulher vítima da agressão" (Vieira, 2018, p. 42). Nota-se que, assim, ele se exime da responsabilidade e utiliza outras pessoas e acontecimentos para fundamentar seus próprios atos violentos.

Tais discursos demonstram o ciúme patológico, baseado na fusão e posse que um tem sobre o outro.A pessoa que sente tal ciúme acredita que é como se o casal fosse um só, e "quando a mulher não corresponde mais à imagem que o homem idealizou, ao expressar sua autonomia e identidade, começam as suspeitas e os conflitos" (Cavalcante, 1997, apud Centeville; Almeida, 2007, p. 87).

Também foram identificados, durante a entrevista, discursos que caracterizam relacionamentos abusivos, ${ }^{4}$ influenciados diretamente por

4 Esses modelos de relacionamento podem estar presentes em qualquer relação, seja de amizade, no local de trabalho, em relações amorosas heterossexuais ou homossexuais, com pessoas de todas as idades, cor e classe social. 
um ciúme patológico e uma masculinidade que defende a subordinação do sexo feminino ao masculino.

No caso de "P7", ${ }^{5}$ foi analisado, pelas suas falas, que ele, sutilmente, foi impondo certas regras de convivência a sua companheira. Como a família dela não o aceitava, observou-se durante a entrevista que aos poucos ele a foi afastando dos filhos, irmãos e outras pessoas com quem ela mantinha relacionamentos sociais. Sua principal estratégia foi ficar sempre com ela: "A gente é muito agarrado em tudo que nós fossemos fazer, fazíamos sempre juntos”. Após a detenção por cárcere privado, esse homem, assim como os demais participantes da entrevista, culpabilizou a companheira: "Ela foi criando esse ambiente" (Vieira, 2018, p.43).

$O$ relacionamento abusivo se institui em uma relação por meio de pequenas imposições no dia a dia, como o que vestir, com quem se relacionar, através de agressões verbais, físicas, psicológicas, sexuais, até mesmo abusos financeiros, ao controlar o dinheiro do outro. $\mathrm{O}$ intuito é ter o controle sobre o outro, demonstrando atitudes extremamente ciumentas, e culpabilizando o outro por todas as ações (Carta Capital, 2018).

\section{Impulsividade}

A sensação de injustiça perpassou todos os momentos da entrevista. Em diversos discursos, os homens entrevistados trouxeram em suas falas o quanto se sentiram injustiçados, seja pelo sistema jurídico, seja por terem tido uma ação violenta que foi "meramente reativa", visto que reagiram a uma primeira violência exercida pela mulher.

ela pegou e não gostou daquilo que fiz, e jogou a bicicleta nas minhas costas [...] a minha foi a primeira, mas ela já tinha acontecido das outras vezes né, dentro do carro ela me agrediu, tacou o celular na minha cara. (P5) (Vieira, 2018, p. 44)

Para ter acesso a todas as entrevistas na íntegra, basta acessar a pesquisa: "Compreendendo a violência doméstica a partir dos depoimentos de homens autores de violência contra a mulher". 
No entanto, sabe-se que atos como os expressos nas falas dos entrevistados, podem ser caracterizados - estes sim - como atos meramente reativos tendo em vista o contexto violento que caracteriza a sociedade machista. (Vieira, 2018, p. 44)

O agir sem pensar também aparece como justificativa ao ato violento. Esses homens, autores de violência doméstica, interligam suas ações violentas com uma mera reação impulsiva. $O$ padrão de masculinidade hegemônica institui o sexo masculino como "um ser não emocional", mas que paradoxalmente "pode" responder aos problemas cotidianos de forma violenta e, após o arrependimento, argumentar que tal atitude foi um impulso. Durante muito tempo a violência contra a mulher foi identificada como ato passional.

Foi o impulso, porque se eu tô casado com ela 25 anos, jamais eu vou, e eu sou contra, eu sempre fui contra um homem bater numa mulher, eu sempre fui contra entendesse, eu não aceito um homem bater numa mulher, entendesse, se eu tivesse casado numa passa de um a dois anos, tudo bem, não tem o que, né? (P2) (Vieira, 2018, p. 44)

Nesse último discurso fica evidente que a violência doméstica contra a mulher ainda está longe de ser reconhecida e compreendida. $O$ entrevistado desqualifica a violência doméstica ao afirmar que tal violência só pode ser caracterizada se for recorrente, pois para ele "não é a qualidade do ato, mas sim a quantidade de atos que faria alguém ser reconhecido como violento" (Vieira, 2018, p. 2018)

\section{A ambiguidade da mulher}

As características, o jeito, a maneira de se portar das mulheres na sociedade foram fortemente descritas nos discursos dos homens entrevistados. Inclusive foram associados à "justificativa" dos atos violentos masculinos. 
é uma boa mãe, foi uma boa esposa [...] cuida de mim, cuida da casa, de tudo, lembrava de tudo, não deixava faltar nada, nunca me deixou faltar nada. Ela acordava todos os dias às quatro da manhã pra fazer meu café, tanto que esse dia que eu cheguei às quatro horas da manhã, ela tava de pé já pra fazer o meu café, tudo. Então, ela tem os seus pontos de respeito, ela é muito respeitadora, é uma pessoa moça de família, muito especial [...] ela é uma pessoa, como eu te disse é pessoa especial, muito boa pessoa, pessoa de, com uma índole muito, muito, muito linda, então... boa mãe, prestativa, foi uma boa mulher, cuida, cuidou sempre muito bem de mim, de tudo, as minhas roupas, o meu uniforme, até o meu, a minha bota de trabalho sempre limpinha, ela sempre foi dedicada, trabalhava, tinha sua educação, cuida da casa (P1) (Vieira, 2018, p. 45)

Observa-se que a feminilidade admirada por esses homens é aquela considerada "normal" pelo padrão de masculinidade hegemônica, aquela mulher "passiva, sentimental, submissa ao homem” (Vieira, 2018, p. 57), responsáveis pelos afazeres domésticos, pelo cuidado com os filhos. Esses discursos apresentam uma clara separação entre qual o papel do homem e qual o papel da mulher em uma relação, em que o homem deve ser o provedor do lar, aquele que se coloca como a figura de poder dentro do ambiente doméstico, e a mulher aquela que deve cuidar de tal ambiente, deixá-lo limpo e organizado para satisfazer o detentor do poder, “tornando-se uma 'escrava doméstica” (Vieira, 2018, p. 45).

Baseando-se em um discurso machista, aparece nas falas dos entrevistados a figura da mulher ingrata, aquela que não valorizou o que o homem fez por ela: "Ela é uma pessoa hipócrita, que não soube dar valor o que eu construí pra ela [...]" (P5) (Idem). A superioridade que o sexo masculino acredita ter perante o sexo feminino é tão alta que, nessas falas, mesmo diante o fato de tais mulheres terem sido agredidas, colocadas em um patamar de submissão, esses homens acreditam que elas foram mal-agradecidas por terem se separado e, inclusive, por terem registrado Boletim de Ocorrência. É como se o fato de as terem provido financeiramente desse a eles o direito de agredi-las. 
Ah! era igual tipo, você chegava em casa os primeiros dois mês assim, era comida na mesa, essas coisas, daí depois não foi aquilo que você começou, daí não tava me agradando. (P6) (Vieira, 2018, p. 46)

Discursos como esse, que trazem o homem como o provedor do lar no âmbito financeiro, se relacionam com a concepção machista de que o sexo feminino é o sexo frágil, que deve se impor aos desejos do sexo oposto, trazendo a impressão "de que o homem acredita que pode tratar a mulher como se fosse parte de seu patrimônio" e que pode tratá-la como "convier, inclusive, ser violento, porque ele é o responsável por sustentar financeiramente o lar" (Vieira, 2018, p. 46).

[...] tinha comprado a muleta fazia uma semana, e eu ainda peguei falei pra ela: "olha, XX o que cê tá fazendo comigo".Só que a mulher, os cinco minutos da mulher ela põe uma vida a perder, porque a mulher age no impulso da situação, do nervosismo, do ódio. (P4)

[...] nervosa, que a mãe dela já, quando eu comecei a namorar com ela, a mãe dela falou que ela tinha um gênio muito forte, então, o primeiro marido dela já passou o mesmo trabalho que eu passei, em questão policial, porque tudo ela chama a polícia, né, e isso não vem ao caso porque eu não tive a paciência de suportar também. (P5) (Vieira, 2018, p. 46)

A verdadeira vítima do ato violento, a mulher, é apresentada nos discursos ora como "uma boa pessoa, ora como uma pessoa que tem problemas" (Vieira, 2018, p. 47). Elas são descritas como passionais, impulsivas, emotivas, irracionais: "la até é uma pessoa normal, [...] o negócio dela é bater, mas sem isso aí ela é normal” (P2) (Idem). As falas trazem positividade na visão desses homens em relação às mulheres, mas logo em seguida sempre frisam muito a ideia da mulher impulsiva e insana que motiva os atos violentos.

[...]é uma supermulher. [...] Ela me ajuda em tudo, é uma mulher que, ela me completa tanto na parte sentimental, como mãe, esposa, é que nem eu 
te falei o que motiva as brigas são o nervosismo dela, os problemas dela, toma calmante [...] (P4) (Idem)

Os discursos revelaram a todo momento uma tentativa de responsabilizar a mulher por atos violentos que foram sofridos por elas mesmas. Esses homens não trazem reconhecimentos em si como sujeitos responsáveis pelo ato, colocando a culpa no outro. Mesmo sem admitirem, suas falas demonstram "que há uma transferência de responsabilidade pelo ato violento" (Idem).

Porque ela via que ali era o meu ponto fraco, então ela usava aquilo ali como um álibi, pra que pra gerar briga e discussão, muitas vezes, muitas vezes não, sempre fui errado porque eu chegava sempre num ponto de levantar a mão, sempre cheguei no ponto, porque, porque assim ó, ela tirava a gente do sério [...]. Só quando ela me agredia, ela me agredia várias vezes, né. [...] ela acabou com a minha paciência, eu era uma pessoa passiva, eu não era uma pessoa estressada e nem nervosa. [...] não tô botando a culpa nela, tá, porque quando ela me conheceu ela me conheceu daquele jeito, entendeu [...]. (P5) (Idem)

O discurso supracitado fundamenta a violência praticada como se fosse resultado de uma premeditação da própria mulher. Como se o ato violento fosse resultado de uma estratégia tramada pela própria vítima da violência em "benefício próprio". Ele a coloca como uma figura manipuladora. A fala de "P5" adultera e menospreza a realidade, pois é ela mesma, a mulher, quem é o alvo dos atos violentos.

Outro elemento que comparece é, de um lado, a apresentação, pela figura masculina, de uma condição que se deve aceitar, pois que não irá mudar - é de um jeito e assim permanecerá. Diante de um comportamento instalado, cabe à parceira a aceitação. A crítica branda que se faz ao ato cometido é sempre desproporcional à avaliação que se faz do comportamento assumido pela companheira. Ela é a irresponsável, impulsiva, leviana, ingrata. Ele é o sujeito que merece ser considerado, compreendido e aceito tal como é. 
Eu peguei fui tomar a mochila dela, e ela me chutando, me chutando, puxando a mochila, [...] nisso eu tomei a mochila dela e ela subiu correndo pro posto, e eu tô dentro do caminhão com meus filhos, só que o segurança já tinha visto que eu tava puxando a mochila e ela me chutando, só que eu não cheguei agredir, dar soco nela, muito pelo contrário, eu que tomei, que ela é bem maior que eu[...].Conclusão: ela pegou voltou pro caminhão, dormiu no caminhão, e eu fui preso; se ela tivesse me ouvido a hora que eu falei pra ela dormir no caminhão e outro dia ir embora [...].(P4) (Vieira, 2018, p. 48)

O aborrecimento, de acordo com "P4", foi o fato de a sua companheira não ter ouvido e acatado o que ele dizia. "E, ainda, ter senso de prontidão não apenas em relação ao que é dito, mas ao momento em que é dito" (Idem). Perpassando a ideia de que o masculino é superior ao feminino, na visão de "P4", sua esposa deveria cumprir com o que seu marido a "aconselha". Desta forma, as situações de violência seriam evitadas. Esse discurso é mais uma tentativa de retirar de si a responsabilidade pelos seus atos e transferi-la para a mulher que foi agredida.

\section{Desconsideração do seu ponto de vista}

Então assim, eu eu acho importante essa, esse estudo em cima dessa questão, porque muitas vezes é ouvido mais as mulheres e ocultam um pouco a veracidade dos fatos $\mathrm{da} / \mathrm{na}$ hora que aconteceu, que o homem não tem direito a defesa caso aconteça um um uma agressão, os dois tiveram discutindo e aí só se ouve a mulher (P1).

Como ela disse que fui eu que agredi, porque homem nunca tem razão do que fala né, primeiro elas, a mulher tá em primeiro lugar. (P5) (Vieira, 2018, p. 49)

Discursos como esses expressam sentimentos de injustiça, em que o homem acredita que a atual legislação o prejudica, privilegiando o sexo oposto. Porém, quando repensamos na historicidade do entendimento jurídico sobre a violência doméstica contra a mulher, nos recordamos 
que foi somente em 2006, por intermédio da Lei Federal no 11.340, que a violência contra a mulher deixou de ser considerada um crime de "menor potencial ofensivo", dispondo de exclusivos Juizados de Violência Doméstica e Familiar contra a Mulher. Além de as mudanças legislativas sobre crimes contra mulheres serem recentes, é de conhecimento geral que cada dia aumenta mais o número de mulheres vítimas de violência doméstica e feminicídio.

Muitos dos participantes avaliam a detenção como uma medida exagerada, sem necessidade. "[...] é assim uma coisa que não precisava tá" (P2). Discursos como estes relembram ao passado brasileiro, que tratava a violência contra a mulher como um ato de menor potencial, desqualificando a gravidade e seriedade deste assunto: "É coisa da cabeça dela, qualquer coisa ela chama a polícia”. (P5) (Vieira, 2018, p. 50)

Os entrevistados trouxeram em suas falas indignações sobre como são tratados pelos policiais, tanto em relação à abordagem quanto como esses policiais "protegem" as mulheres.

[...] a polícia chegou e me prenderam, aí não me falaram nada, eu pedi pro delegado "porque eu tô sendo preso", ele falou "quando chegar na delegacia eu vou saber", aí só quando eu vim saber, só quando eu cheguei aqui. $\mathrm{Na}$ delegacia não falaram nada, o cara tava entrevistando umas coisas, que eu nem sabia de fato que eu tinha uma Medida Protetiva contra a mulher que eu tava. (P6). Maria da Penha os policiais não chegam e perguntam o motivo, quando é Maria da Penha fala: "Ah!, não é o homem que tá errado", entendeu? Lógico eu não tô transferindo a culpa pra ela, os dois têm parcela de culpa [.... (P4) (Vieira, 2018, p. 50)

Nota-se que, apesar de não admitir, "P4" transfere a ideia de "culpa" para sua companheira, afirmando que seus próprios atos foram resultantes de uma implicância da esposa. Como se ela ativasse a capacidade dele de agredir o outro. "Sendo assim, para ele é um equívoco a Lei Maria 
da Penha acusar o homem como culpado, pois o mesmo só estaria respondendo diante de uma situação que ele mesmo tentou evitar" (Vieira, 2018, p. 50-51).

Durante a entrevista, "P4" menciona o Centro de Referência de Atendimento à Mulher em Situação de Violência (CREMV), que é uma instituição pública que faz parte do Programa de Prevenção e Enfrentamento à Violência contra a Mulher. Deve acolher as mulheres em situação de violência e seus familiares, por meio de atendimentos sociais, psicológicos e orientações jurídicas, com objetivo de romper com a situação de violência (NSC, 2019).

[...] É que nem eu digo, o correto é o CREMV também dar um acompanhamento pros esposo [...] esses casais é o seguinte eles têm que ter uma ajuda do CREMV, não o CREMV separar os casais, porque ó o tanto, o que eles tão fazendo, ó o tanto de criança que vai ficar com pai longe, sem o pai assistir o crescimento da criança [...] que o CREMV faz na realidade não é unir as famílias eles tão separando cada vez mais. E eu penso assim, que o CREMV, eles primeiro têm que fazer uma pesquisa ou uma investigação social da vida do casal, não já pegar e ir tirando filho, esposa [...]

Estimula a mulher a separar, estimula a mulher a sumir, igual agora eles têm um programa de, como é que eu posso dizer, um programa de abrigos, tirando aquela mulher e os filhos, do, na realidade daquele pai de família, porque às vezes um simples erro do pai de família pra corrigir é com uma psicóloga, não ela afastando a família, ela afastando a família a situação fica pior, eu tô sofrendo, não vou mentir pra você, tô sofrendo demais, então o que acontece pessoal do CREMV que é da defesa da mulher, eles têm que pensar no nosso lado também, eles tem que pensar no nosso lado, sabe eu não sou agressivo sem bebida. (P4) (Vieira, 2018, p. 50-51)

O objetivo principal do CREMV incomoda "P4", pois em sua visão essa instituição deveria zelar pela "família", pela "união do casal". Ele compreende que é penalizado pelo CREMV, à medida que a instituição orienta a mulher a se proteger na relação violenta, ou seja, do autor da violência, pois assim ele acredita que sua companheira foi influenciada 
a deixá-lo, "ainda que ele represente a maior ameaça para a [...] continuidade (do casamento)" (Vieira, 2018, p. 52).

Um fator que merece destaque e que, certamente, influencia milhares de homens a acreditar que tudo vale a pena, desde que seja em nome do matrimônio familiar, foi que durante a entrevista "P4" relatou estar lendo o livro Casamento blindado, ${ }^{6}$ que já teve mais de meio milhão em vendas. Observa-se que livros como esse fortificam a ideia de posse do homem sobre a mulher, bem como da necessidade que o sexo feminino tem em agradar o sexo masculino. Além de instigar comportamentos heteronormativos baseados no machismo, fortalece diretamente a masculinidade hegemônica, reproduzindo os atos violentos de homens contra mulheres.

O entrevistado P1 argumenta que a lei e o seu cumprimento são desmedidas,

E aí já define um, uma medida protetiva não dando o direito dele mais chegar próximo à esposa.Tirar do lar a família.Tirar a responsabilidade de casa, de tudo, e o homem fica um pouco oculto, não podendo falar aquilo que ele expressa, pra que ele sente, pra que fosse melhor pra convivência do casal, então acaba se distanciando um casamento por falta de comunicação. [...] Automaticamente eles não me deram direito de conversar mais com minha esposa, automaticamente eles me expulsaram da vida da minha filha, automaticamente eles deixaram... eles, eles, eles acabaram com uma coisa que poderia ser mais tranquila, mas com.. mais consciente, conversando tranquilo. Porque por ela tava tudo certo, tanto que eu chegava lá e ela colocava café na mesa pra mim, a gente conversava tranquilo. (P1) (Vieira, 2018, p. 51)

6 Escrito por Renato Cardoso (bispo da Igreja Universal do Reino de Deus) e sua companheira Cristiane Cardoso (filha do bispo Edir Macedo, dono e fundador da Igreja Universal). A primogênita de Edir Macedo também apresenta com seu companheiro um programa de televisão e já trouxe relatos como: "sexo antes do casamento é inaceitável, mas depois de casada a mulher deve fazê-lo sempre que o marido quiser - e não me venham com essa história de dor de cabeça!"(Barroso, 2013, apud Vieira, 2018, p. 54-55). 
A forma como o Poder Judiciário atua é fortemente criticada durante as entrevistas. As falas desses homens trazem sensações de desrespeito, de sentirem que não são compreendidos e que são duramente afastados de suas famílias. Nesses momentos, os entrevistados esquecem a gravidade de suas ações e se colocam como vítimas de um Estado que quer destruir a "família tradicional". Como se o principal objetivo do Poder Judiciário devesse ser restabelecer o casamento, e não combater uma sociedade machista que influencia diretamente a violência doméstica contra a mulher cometida por parceiros. (Vieira, 2018, p. 52).

Os altos índices de violência contra a mulher são dados específicos do quanto as instituições que trabalham com essa questão devem proteger essa mulher em situação de violência doméstica, auxiliando-a a sair de um ciclo violento, mudando sua realidade e a encorajando a não aceitar mais a submissão ao sexo masculino. Auxiliando assim, na criação de novas masculinidades e feminilidades, "a dominação dos homens e a subordinação das mulheres constituem um processo histórico, não um sistema autoreprodutor" (Connell; Messerschmidt, 2013, p. 260).

\section{O autor da violência se vê como vítima}

Na finalização da análise das entrevistas, ficou claro que o autor de violência contra a mulher ainda se vê como vítima, seja do comportamento da companheira, do atual meio jurídico, inclusive de toda a sociedade brasileira.

[...] ela nunca quis essa separação, nunca quis a separação, sempre me agredia. [...] nunca revidei nada, nunca revidei nada e ela me deferiu vários golpes de faca, várias vezes, e eu, também, não fui atrás de delegacia nem nada, porque também tentando ali uma um término melhor do nosso relacionamento. (P1) 
Eu estou aqui porque nós discutimos, eu e minha mulher, entendesse? E no discutir até ofendi ela, eu ofendi ela e ela me deu um tapa no meu rosto e eu... eu como que é, e eu, revidei né, daí eu revidei, daí ela chamou a polícia. (P2) E o que que acontece nessa situação o homem acaba ficando vulnerável, porque o homem também é. Eu tenho comigo que o homem é mais vulnerável que a mulher, tem mulheres aqui de colegas que tão presos aqui, que elas fazem por vingança. Então eu acho que esse CREMV na realidade não deveria estimular a mulher pra poder prejudicar mais a gente, porque a gente só quer trabalhar. (P4) (Vieira, 2018, p. 52-53)

Como se enxergam enquanto "vítimas" de uma realidade social, esses homens acreditam que não merecerem estar detidos, pois se consideram "bondosos" e "nunca fizeram nada de errado":

[...] jamais eu queria que isso tivesse acontecido dentro dessa, dessa forma, dessa proporção que chegou a isso, e eu estar aqui nesse lugar, que eu jamais pisei na minha vida. Tô com quarenta e poucos anos e não, jamais, pensava em, nunca pisei na minha vida, nunca cheguei a esse ponto, nunca foi preciso chegar a esse ponto, sempre tive, eu dei o, sempre falando: "Não você fique com tudo que eu vou embora e, não quero discussão". (P1)

Que eu acho injusto, você prende uma pessoa, eu não tenho passagem pela polícia, não tenho nada, nunca fiz nada de errado, eu fui acusado de uma coisa que não fiz e tô aqui e não sei se eu perdi meu trabalho, não sei nada, só me prenderam e me trouxeram pra cá. (P6)

Então nós na realidade nós não necessitamos de tá preso num local igual a esse, mais sim de uma ajuda psicológica tanto homem quanto a mulher. Lógico sou a favor da Lei Maria da Penha, o homem que agride, espanca a mulher... eu sou a favor, né! Mas no meu caso, como no caso de outros que tão aí dentro, estavam trabalhando [...]. (P4) (Vieira, 2018, p. 53-54).

É tanta a dificuldade em perceber-se como um ser agressivo, que se torna mais fácil criar uma figura de homem "vulnerável" e de mulher "vingativa”. Para esses homens, criticar a imagem do sexo feminino é mais fácil do que modificar as ações do sexo masculino. 


\section{Considerações finais}

Basta uma rápida e simples busca nas páginas da internet para observamos o número elevado de notícias sobre mulheres que foram mortas e violentadas por companheiros/ex-companheiros. Alguns exemplos: em uma entrevista realizada pela equipe de reportagens do G1, no dia 8 de março de 2019, dia Internacional da Mulher, foi constatado que em 2018, em Sergipe, 1500 mulheres foram ameaçadas e outras 37 foram mortas vítimas de violência doméstica. E nos primeiros dezenove dias do ano de 2019 já haviam sido instaurados mais de 320 inquéritos de violência contra a mulher em Rio Branco (AC) (Lima, 2019). No dia 18 de fevereiro de 2018, a Secretaria do Estado de Segurança Pública de Santa Catarina divulgou no seu Boletim Semanal que em Santa Catarina foi registrado pelo menos um caso de feminicídio por semana (NSC, 2019).

Fica evidente que os casos de violência contra a mulher estão crescendo e são necessárias discussões de vários segmentos da sociedade. Destaca-se a importância de estudar e trabalhar com todos os personagens que fazem parte desse ciclo de violência. Compreende-se que os homens são os atores fundamentais na reprodução dessa violência, eles que muitas vezes ocupam o papel de autor de violência, e necessitam da realização de trabalhos psicossociais baseados no feminismo e na igualdade entre os sexos.

As falas analisadas, mais que dados da compreensão dos autores de violência sobre suas atitudes, são demonstrativas da urgência de políticas que considerem a masculinidade hegemônica como determinante para a produção e a reprodução da violência doméstica.

Ao manifestarem que são injustiçados, os homens demonstram o desconforto vivido quando é rompido ou afetado o seu lugar de autoridade na relação. Para eles, a causa do seu ato violento é sempre dada por uma exterioridade absoluta e incontrolável, na qual a sua companheira encontra-se em um lugar ambíguo, muitas vezes ameaçador. Alegam, também, que os dispositivos jurídicos não o reconhecem como sujeitos a serem considerados, razão pela qual consideram-se vítimas de todo o processo. 
Os direitos conquistados pelo movimento feminista representam avanços na construção de uma relação equitativa entre homens e mulheres, mas ainda enfrentam a lentidão do reconhecimento social, talvez devido ao não questionamento por parte dos homens sobre a sua responsabilidade em, também, alterarem essa relação, de modo a saírem da constelação de privilégios dos quais usufruem (por exemplo, maior inserção no espaço público, nos cargos de comando e decisão políticos, melhores salários etc.). Isso demonstra a necessidade de políticas públicas destinadas à formação de uma cultura na qual homens e mulheres constituam relações igualitárias, capazes de promover um processo crítico à relação que objetifica mulheres e que reitera a masculinidade como sinônimo de opressão.

\section{Referências}

BEIRAS, A. et al.Gênero e super-heróis: o traçado do corpo masculino pela norma. Psicologia \& Sociedade, Belo Horizonte, v. 19, p. 62-67, 2007.

BRASIL. Presidência da República. Lei no 11.340, de 7 de agosto de 2006. Cria mecanismos para coibir a violência doméstica e familiar contra a mulher. Disponível em: www. planalto.gov.br/CCIVIL/_Ato2004-2006/2006/Lei/L11340.htm. Acesso em: 13 nov. 2017.

CENTEVILLE, Valéria; ALMEIDA, Thiago de. Ciúme romântico e a sua relação com a violência. Psicologia Revista, São Paulo, v. 16, n. 1 e 2, p.73-91, 2007. Disponível em: http://www.thiagodealmeida.com.br/site/wp-content/uploads/Ciume_romantico_e_a_ sua_relacao_com_a_violencia.pdf. Acesso em: 22 out. 2018.

COMO começa um relacionamento abusivo? Carta Capital, fev. 2018. Disponível em: https://www.cartacapital.com.br/sociedade/Como-comeca-um-relacionamento-abusivo. Acesso em: 8 nov. 2018.

CONNELL, Robert W.; MESSERSCHMIDT, James W. Masculinidade hegemônica: repensando o conceito. Estudos Feministas, Florianópolis, v. 21, n. 1, p. 241-282, maio 2013. ISSN 1806-9584. Disponível em: https:/periodicos.ufsc.br/index.php/ref/article/view/S0104026X2013000100014. Acesso em: 23 jan. 2017.

FLORIANÓPOLIS. Centro de Referência de Atendimento à Mulher em Situação de Violência - CREMV. 2018. Disponível em: http://www.pmf.sc.gov.br/servicos/index. php?pagina=servpagina\&id=4610. Acesso em: 2 jun. 2019. 
LIMA, Lillian. Em 19 dias, mais de 320 inquéritos de violência contra a mulher são instaurados em Rio Branco. Rede Amazônica - Acre, Rio Branco. fev. 2019. Disponível em: https:/g1.globo.com/ac/acre/noticia/2019/02/26/em-19-dias-mais-de-320-inqueritosde-violencia-contra-a-mulher-sao-instaurados-em-rio-branco.ghtml. Acesso em: 19 maio 2019.

NASCIMENTO, Pedro. Beber como homem: dilemas e armadilhas em etnografias sobre gênero e masculinidades. Revista Brasileira de Ciências Sociais, Paraíba, v. 31, n. 90, p. 57-71, fev. 2016. Disponível em: http://www.scielo.br/pdf/rbcsoc/v31n90/0102-6909rbcsoc-31-90-0057.pdf. Acesso em: 19 maio 2019.

NISCASTRE, Sérgio. Drogas: classificação e efeitos no organismo. In: BRASIL. Secretaria Nacional de Políticas Sobre Drogas (Ed.). Prevenção ao uso indevido de drogas: capacitação para conselheiros e lideranças comunitárias. 4. ed. Brasília: UFSC, 2011. p. 17-38.

NSC TOTAL. Santa Catarina tem mais de um feminicídio por semana em 2019. Florianópolis. fev. 2019. Disponível em: https://www.nsctotal.com.br/noticias/santacatarina-tem-mais-de-um-feminicidio-por-semana-em-2019. Acesso em: 19 maio 2019.

TV SERGIPE. Mais de 1500 mulheres foram ameaçada e outras 37 morreram vítimas de violência em Sergipe. mar. 2019. Disponível em: https://g1.globo.com/se/sergipe/ noticia/2019/03/08/mais-de-1500-mulheres-foram-ameacada-e-outras-37-morreramvitimas-de-violencia-em-sergipe.ghtml. Acesso em: 19 maio 2019.

VIEIRA, Amália Einhardt Alves. Compreendendo a violência doméstica a partir dos depoimentos de homens autores de violência contra a mulher.2018. Trabalho de Conclusão de Curso (Serviço Social) - Universidade Federal de Santa Catarina, Florianópolis, 2018. Disponível em: https://repositorio.ufsc.br/handle/123456789/195738. Acesso em: 2 jun. 2019.

\section{Sobre as autoras}

Amália EInHARdT - Assistente social.

E-mail: dss@contato.ufsc.br

Simone Sobral Sampaio - Assistente social, professora Dra. de Serviço Social, no âmbito da graduação e pós-graduação.

E-mail: simone.s@ufsc.br 